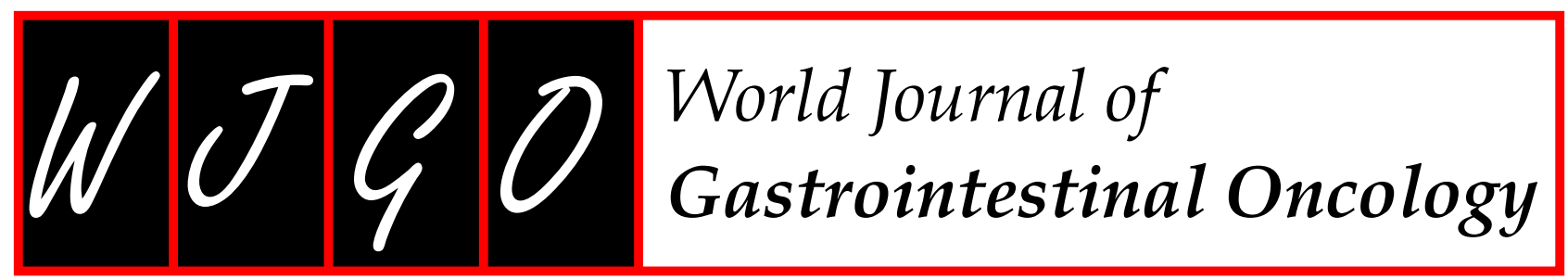

Online Submissions: http:/ / www.wjgnet.com/esps/ wjgo@wjgnet.com

World J Gastrointest Oncol 2013 October 15; 5(10): 195-197 doi:10.4251/wjgo.v5.i10.195

ISSN 1948-5204 (online)

(c) 2013 Baishideng. All rights reserved.

\title{
Obstructive jaundice due to a rare periampullary tumor
}

\author{
Anjana Sathyamurthy, Abhishek Choudhary, Dennis Ng, Shuaib Okponobi, Alberto Diaz-Arias, \\ Ajitinder Grewal, Ghassan M Hammoud
}

Anjana Sathyamurthy, Abhishek Choudhary, Dennis Ng, Ajitinder Grewal, Ghassan M Hammoud, Division of Gastroenterology and Hepatology, University of Missouri-Columbia, Columbia, MI 65212, United States

Shuaib Okponobi, Alberto Diaz-Arias, Department of Pathology and Anatomical Sciences, University of Missouri Health Sciences Center, Columbia, MI 65212, United States

Author contributions: Sathyamurthy A wrote the manuscript; Choudhary A, Ng D and Grewal A were involved in reviewing the literature; Okponobi S and Diaz-Arias A provided pathology slides and interpretation; Hammoud GM Corresponding author, edited and revised the manuscript.

Correspondence to: Ghassan M Hammoud, MD, MPH, Associate Professor of Clinical Medicine, Division of Gastroenterology and Hepatology, University of Missouri-Columbia, One Hospital Drive, CS and E Building, CE405, Columbia, MI 65212, United States. hammoudg@health.missouri.edu Telephone: +1-573-8828586 Fax:+1-573-8844595 Received: June 20, 2013 Revised: August 30, 2013

Accepted: September 3, 2013

Published online: October 15, 2013

\section{Abstract}

Gangliocytic paraganglioma is a rare neuroendocrine tumor predominantly arising in the second part of the duodenum with rare local recurrence or metastasis to regional lymph nodes. A 92-year-old female presented with obstructive jaundice. On exam she had pale conjunctiva and icteric sclera. Abdominal examination revealed tenderness in the upper abdomen. Laboratory data was consistent with obstructive jaundice. Computed tomography of the abdomen revealed a dilated gall bladder and a common bile duct (CBD) with no evidence of liver lesions or pancreatic head mass. Endoscopic ultrasonography revealed a $1 \mathrm{~cm}$ isoechoic submucosal nodule at the periampullary area, dilated CBD $(9 \mathrm{~mm})$, a prominent pancreatic duct $(4.1 \mathrm{~mm})$ and a hydropic gall bladder with no stones. Endoscopic retrograde cholangiopancreaticography was performed to relieve obstruction and showed a $1 \mathrm{~cm}$ periampullary mass which underwent an en-bloc snare resection. Histopathology analyses with immunohistochemical stains were positive for cytokeratin, synaptophysin, S-100 protein, neuron specific enolase and negative for actin and desmin consistent with periampullary gangliocytic paraganglioma. Periampullary gangliocytic paraganglioma is a rare benign tumor of the small bowel. Common presentation includes abdominal pain and obstructive jaundice which should be included in differential diagnosis of obstructive jaundice. Endoscopic resection is a curative therapy in the absence of local invasion or distant metastasis.

\section{(c) 2013 Baishideng. All rights reserved.}

Key words: Gangliocytic paraganglioma; Periampullary tumor; Spindle-shaped; Epitheloid; Ganglion cells; Jaundice; Duodenum; Endoscopic mucosal resection

Core tip: This case report shed some light on a rare cause of obstructive jaundice in elderly patients. The disease is rare but should be considered in the differential diagnosis of biliary obstruction. The literature provided summarizes several outcomes of case presentation with this disorder and provide input on some of the aggressive feature of this disorder.

Sathyamurthy A, Choudhary A, Ng D, Okponobi S, Diaz-Arias A, Grewal A, Hammoud GM. Obstructive jaundice due to a rare periampullary tumor. World J Gastrointest Oncol 2013; 5(10): 195-197 Available from: URL: http://www.wjgnet.com/1948-5204/ full/v5/110/195.htm DOI: http://dx.doi.org/10.4251/wjgo.v5.i10.195

\section{INTRODUCTION}

Gangliocytic paraganglioma is a rare neuroendocrine tumor predominantly arising in the second part of the duodenum with rare local recurrence or metastasis to regional lymph nodes. We present a case of a 92-year-old female with abdominal pain, obstructive jaundice and a mass in the second portion of the duodenum, near the papillary region. 

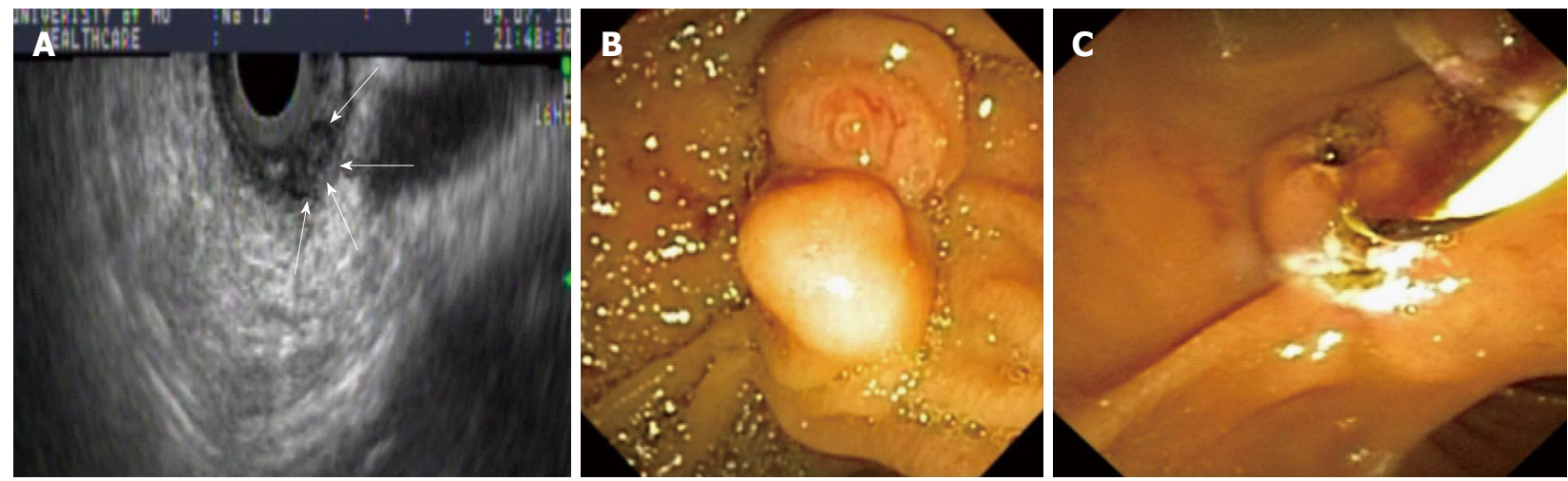

Figure 1 Endoscopic images of periampullary tumor prior and after endoscopic mucosal resection. A: A $1 \mathrm{~cm} \times 1.5 \mathrm{~cm}$ isoechoic, submucosal nodule near the major ampulla (arrows); B: Periampullary submucosal nodule with a normal overlying mucosa; C: Lesion post endoscopic mucosal resection.
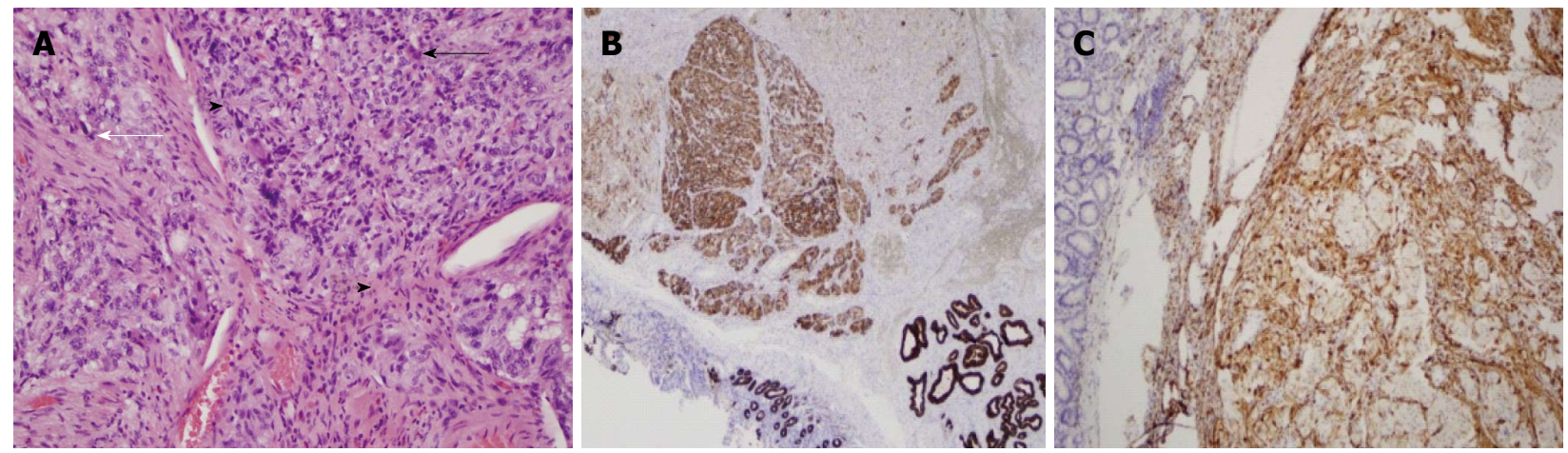

Figure 2 Histologic characteristics of the gangliocytic paragangliomas. A: Submucosal location of the peri-ampullary tumor ( $\mathrm{H}$ and $\mathrm{E}$, original magnification $\times 2$ ); Epitheliod cells (black arrow) with surrounding spindle cells (white arrow). Ganglion-like cells present (arrow heads) ( $\mathrm{H}$ and E, original magnification $\times 20$ ); B: Immunohistochemistry of tumor showing positivity for cytokeratin in the epitheliod cells (original magnification $\times 4$ ); C: Immunohistochemistry of tumor showing S-100 positivity of the spindle cell component (original magnification $\times 10$ ).

\section{CASE REPORT}

A 92-year-old female presented with upper abdominal pain associated with nausea, vomiting and jaundice for $4 \mathrm{~d}$. She had no history of fever, chills, melena, hematemesis or weight loss. Her past medical history was significant for diabetes, hypertension, gastroesophageal reflux, chronic renal insufficiency and hypothyroidism.

Physical examination revealed pale conjunctiva and icteric sclera with no cervical lymphadenopathy. Abdominal examination revealed tenderness in the upper abdomen with no rebound tenderness. She had no hepatosplenomegaly or palpable masses. Bowel sounds were present. Laboratory data were significant for hemoglobin $9.7 \mathrm{~g} / \mathrm{dL}$, total bilirubin $2.4 \mathrm{mg} / \mathrm{dL}$, aspartate aminotransferase $166 \mathrm{U} / \mathrm{L}$, alanine aminotransferase $465 \mathrm{U} / \mathrm{L}$, and alkaline phosphatase $515 \mathrm{U} / \mathrm{L}$. Her white cell count, serum amylase and lipase were normal. Computed tomography of abdomen revealed a dilated gallbladder and common bile duct $(\mathrm{CBD}=9 \mathrm{~mm})$ with no evidence of liver lesions or pancreatic head mass. Endoscopic ultrasound (EUS) revealed a well-defined, $1 \mathrm{~cm} \times 1.5 \mathrm{~cm}$ heterogeneous, isoechoic, periampullary submucosal nodule (Figure 1A). The nodule appears to cause an extrinsic compression of the CBD at the ampullary orifice. The CBD was dilated at $10 \mathrm{~mm}$ in diameter and the pancreatic duct (PD) appeared mildly prominent and measured $4.1 \mathrm{~mm}$ in diameter. The gallbladder appeared hydropic with no stones. The lesion did not appear to invade the CBD, PD or muscularis propria layer of the duodenal wall (Figure 1A). Endoscopic retrograde cholangiogram with biliary sphincterotomy was performed to relieve jaundice and showed a $1.5 \mathrm{~cm} \times 2.0 \mathrm{~cm}$ periampullary nodule that partially obstruct the orifice of the major papilla (Figure 1B) which underwent en-bloc endoscopic mucosal resection with electrocautery snare (Figure 1C). Upon follow up, jaundice resolved once resection of the lesion was performed. There were no lymph nodes seen on EUS examination. Histopathology analyses with immunohistochemical stains were positive for cytokeratin (Figure 2B), synaptophysin, S-100 protein (Figure 2C), neuron specific enolase and negative for actin and desmin confirming the diagnosis of periampullary gangliocytic paraganglioma (Figure 2A). The margins were free of tumor and there were no histologic findings of aggressive behavior such as mitosis and/or pleomorphism.

\section{DISCUSSION}

Gangliocytic paragangliomas are exceedingly rare tumors that arise in close proximity to the papilla of Vater and 
Table 1 Summary of case reports, findings and outcome from selected publications

\begin{tabular}{|c|c|c|c|c|}
\hline Author & Presentation & Endoscopic findings & Outcome & Conclusion \\
\hline Kwon et $a l^{[5]}$ & $\begin{array}{l}56 \text { yr old male } \\
\text { with melena }\end{array}$ & $\begin{array}{l}\text { EGD-tumor of ampulla } \\
\text { of Vater with bleeding on } \\
\text { surface }\end{array}$ & Pancreaticoduodenectomy & $\begin{array}{l}\text { If followed up after a diagnosis, local } \\
\text { excision can be curative, avoiding } \\
\text { surgery or lymph node dissection }\end{array}$ \\
\hline Okubo et $a l^{[6]}$ & $\begin{array}{l}61 \text { yr old male with } \\
\text { epigastric } \\
\text { pain and melena }\end{array}$ & $\begin{array}{l}\text { EGD, ERCP, EUS-tumor } \\
\text { of papilla of Vater }\end{array}$ & $\begin{array}{l}\text { Pylorus-preserving } \\
\text { Pancreaticoduodenectomy } \\
\text { and lymph node dissection; } \\
\text { Lymph nodes positive }\end{array}$ & $\begin{array}{l}\text { Do not limit to local resection, as disease } \\
\text { recurrence, lymph node involvement or } \\
\text { distant metastases may occur }\end{array}$ \\
\hline Witkiewicz et $a l^{[7]}$ & $\begin{array}{l}38 \text { yr old female with right } \\
\text { upper quadrant } \\
\text { abdominal pain }\end{array}$ & $\begin{array}{l}\text { EGD-mass in duodenum } \\
\text { near ampulla of Vater }\end{array}$ & $\begin{array}{l}\text { Endoscopic excision of mass } \\
\text { followed by pylorus-preserving } \\
\text { pancreaticoduodenectomy as } \\
\text { margin was positive }\end{array}$ & $\begin{array}{l}\text { It may recur or metastasize; hence pancre- } \\
\text { aticoduodenectomy with lymph node } \\
\text { dissection might be indicated for large } \\
\text { lesions with infiltrative margin or } \\
\text { lesions with pleomorphism and mitoses }\end{array}$ \\
\hline Morita et al ${ }^{[8]}$ & $\begin{array}{l}53 \text { yr old male with } \\
\text { incidental } \\
\text { finding on EGD }\end{array}$ & $\begin{array}{l}\text { EUS-submucosal tumor } \\
\text { in the } 3^{\text {rd }}-4^{\text {th }} \text { layer }\end{array}$ & $\begin{array}{l}\text { Endoscopic mucosal } \\
\text { resection }\end{array}$ & $\begin{array}{c}\text { Endoscopic removal is an alternative } \\
\text { to surgical resection if no local or } \\
\text { distant invasion }\end{array}$ \\
\hline Sakhuja et al $l^{[9]}$ & $\begin{array}{l}33 \text { yr old male with } \\
\text { obstructive jaundice }\end{array}$ & $\begin{array}{l}\text { ERCP-periampullary } \\
\text { growth }\end{array}$ & Pancreaticoduodenectomy & $\begin{array}{l}\text { Recognize and diagnose this rare } \\
\text { benign entity (with } 3 \text { components } \\
\text { on } \mathrm{H} \text { and } \mathrm{E} \text { sections) }\end{array}$ \\
\hline Evans et al $l^{[10]}$ & $\begin{array}{l}56 \text { yr old male with } \\
\text { epigastric pain, vomiting } \\
\text { and obstructive jaundice }\end{array}$ & $\begin{array}{l}\text { EGD-pedunculated } \\
\text { ampullary tumor }\end{array}$ & $\begin{array}{l}\text { Pylorus-preserving } \\
\text { total pancreatectomy }\end{array}$ & $\begin{array}{l}\text { Benign entity-2 yr post } \\
\text { procedure no recurrence of tumor }\end{array}$ \\
\hline
\end{tabular}

EGD: Esophagogastroduodenoscopy; ERCP: Endoscopic retrograde cholangiopancreaticography; EUS: Endoscopic ultrasound.

$90 \%$ are found in the second part of the duodenum ${ }^{[1]}$. The disease is common in the $5^{\text {th }}$ decade and the incidence is slightly higher in males with M:F ratio 1.8:1. Gangliocytic paragangliomas are epithelial (submucosal) tumors with three histological cell types namely epithelioid, ganglion and spindle cells ${ }^{[2]}$.

Typical presentation is abdominal pain, gastrointestinal outlet obstruction and bleeding. However, obstructive jaundice is not common. In our case, jaundice was presumed secondary to mechanical obstruction of the ampullary orifice by the tumor. Immunohistochemistry is positive for cytokeratin, synaptophysin, neuron specific antigen and S-100 protein ${ }^{[2]}$. Endoscopic ultrasonography is useful for preoperative differential diagnosis such as gastrointestinal stromal tumors, carcinoids and periampullary adenoma. The disease generally follows a benign course with rare invasive growth patterns and lymph node metastasis ${ }^{[3,4]}$.

Histologic findings such as increase mitosis, pleomorphism, infiltrative margin and lymph node metastasis are suggestive of potential malignant features ${ }^{[5,6]}$. If feasible, endoscopic resection is a curative therapy in the absence of local invasion or distant metastasis. Table 1 shows summary of case reports, findings and outcome from selected publications ${ }^{[5-10]}$.

\section{REFERENCES}

1 Scheithauer BW, Nora FE, LeChago J, Wick MR, Crawford BG, Weiland LH, Carney JA. Duodenal gangliocytic paraganglioma. Clinicopathologic and immunocytochemical study of
11 cases. Am J Clin Pathol 1986; 86: 559-565 [PMID: 2877566]

2 Perrone T, Sibley RK, Rosai J. Duodenal gangliocytic paraganglioma. An immunohistochemical and ultrastructural study and a hypothesis concerning its origin. Am J Surg Pathol 1985; 9: 31-41 [PMID: 2578747 DOI: 10.1097/00000478-198501000-00007]

3 Dookhan DB, Miettinen M, Finkel G, Gibas Z. Recurrent duodenal gangliocytic paraganglioma with lymph node metastases. Histopathology 1993; 22: 399-401 [PMID: 8514287 DOI: 10.1111/j.1365-2559.1993.tb00145.x]

4 Hashimoto S, Kawasaki S, Matsuzawa K, Harada H, Makuuchi M. Gangliocytic paraganglioma of the papilla of Vater with regional lymph node metastasis. Am J Gastroenterol 1992; 87: 1216-1218 [PMID: 1519587]

5 Kwon J, Lee SE, Kang MJ, Jang JY, Kim SW. A case of gangliocytic paraganglioma in the ampulla of Vater. World J Surg Oncol 2010; 8: 42 [PMID: 20497533 DOI: 10.1186/1477-7819-8-42]

6 Okubo Y, Yokose T, Tuchiya M, Mituda A, Wakayama M, Hasegawa C, Sasai D, Nemoto T, Shibuya K. Duodenal gangliocytic paraganglioma showing lymph node metastasis: a rare case report. Diagn Pathol 2010; 5: 27 [PMID: 20444291 DOI: 10.1186/1746-1596-5-27]

7 Witkiewicz A, Galler A, Yeo CJ, Gross SD. Gangliocytic paraganglioma: case report and review of the literature. J Gastrointest Surg 2007; 11: 1351-1354 [PMID: 17653595 DOI: 10.1007/ s11605-007-0217-9]

8 Morita T, Tamura S, Yokoyama Y, Onishi T, Kuratani Y, Mizuta H, Onishi S. Endoscopic resection of a duodenal gangliocytic paraganglioma. Dig Dis Sci 2007; 52: 1400-1404 [PMID: 17415650 DOI: 10.1007/s10620-006-9370-3]

9 Sakhuja P, Malhotra V, Gondal R, Dutt N, Choudhary A. Periampullary gangliocytic paraganglioma. J Clin Gastroenterol 2001; 33: 154-156 [PMID: 11468445 DOI: 10.1097/0000483 6-200108000-00013]

10 Evans JD, Wilson PG, Barber PC, Neoptolemos JP. Duodenal gangliocytic paraganglioma presenting as an ampullary tumor. Int J Pancreatol 1996; 20: 131-134 [PMID: 8968869]

P- Reviewers El-Karaksy HM, Iacono C, Nakai Y S- Editor Wen LL L- Editor A E- Editor Liu XM 


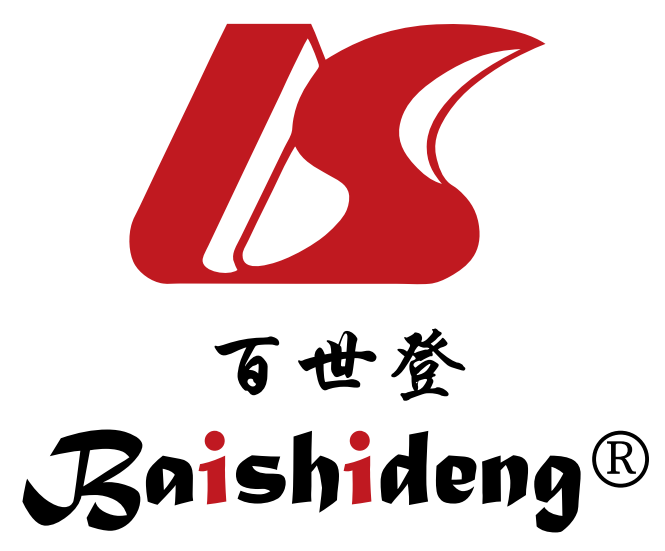

Published by Baishideng Publishing Group Co., Limited Flat C, 23/F., Lucky Plaza, 315-321 Lockhart Road, Wan Chai, Hong Kong, China

Fax: $+852-65557188$

Telephone: $+852-31779906$

E-mail: bpgoffice@wjgnet.com

http://www.wjgnet.com

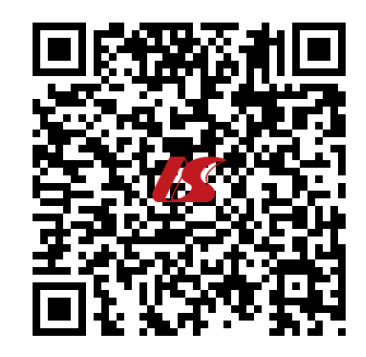

